Lo Bianco, J. (2012) National language revival movements: reflections from India, Israel, Indonesia and Ireland. In B. Spolsky (Ed.), The Cambridge Handbook of Language Policy (pp. 501-522). Cambridge, UK: Cambridge University Press. http://dx.doi.org/10.1017/CBO9780511979026.031

Copyright (C) Cambridge University Press. Reprinted with permission.

\title{
National language revival movements: reflections from India, Israel, Indonesia and Ireland
} Joseph Lo Bianco

\section{Introduction}

The present chapter discusses four radically different socio-political and historical contexts of nationstate making in which language planning in general, and language revival in particular, have been central features. It uses terms originating in discussions about endangered Australian Indigenous languages. All renewal activity is called language revival, divided into three kinds of activity: revitalization, renewal and reclamation (SSABSA 1996). These terms provide a useful overarching framework encompassing the diverse circumstances of the four national case stories: India, Israel, Indonesia and Ireland.

Programmes of language revitalization aim to extend the use of a threatened language among younger generations by drawing on the proficiency of the remaining speakers of a language; language renewal involves activity aiming to increase the usage and knowledge of a language no longer spoken in its full form and language reclamation promotes the re-learning of a language on the basis of historical documentation and archival material.

There are other ways of conceptualizing and dividing the field of language revival, and terms such as retrieval, revival, restoration, reclamation and recovery are used in the academic literature and in the documentation of practice. What is immediately apparent from all these terms is the prevalence of the prefix re-. English prefixes are essentially bound morphemes that supply lexical meaning, and in the case of 're-' that meaning refers to 'getting something back'. In the present discussion national revival movements seek to 'get back' particular languages, those associated with national identities. The need for intervention to cause their return implies that history has intervened, often brutally, in the process of national formation to thwart what might otherwise be an uninterrupted process of development.

Nations are invariably implicated in language revival movements even if the revival activity is not directed towards a 'national language' as such, because all languages exist within a web of communicative ecologies in which speakers have available to them a range of linguistic resources (styles, registers and dialects within languages, and styles, registers and dialects across languages). The communicative choices they make depend on both immediate exigencies and attitudinalideological frameworks.

\section{Languages and nations}

National language revival movements are as different from each other as are nations, languages and political or cultural mobilization. There are fewer than 200 political states in the world as counted by membership of the United Nations, many of which share the same official and officially designated 'national' language. Arabic, English, French, Spanish and Portuguese alone account for more than half the total. This leaves a vast disparity with the more than 6,700 spoken human languages conventionally identified (Lewis 2009). Many of these languages are spoken by groups whose selfdefinition includes an incipient or mature sense of nationality, or at least of separate ethno-cultural existence, some of which actively seek cultural autonomy or separate political statehood.

Four national cases are described briefly here, all discussed within their particular historical trajectories of nationhood, of bounded independent and autonomous polities. All serve a wider sociocultural and political purpose expressed by Ghosh (2004) as 'fixing the language, fixing the national'

We are prone to imagine today that the nation is an almost natural or inevitable form of organization of geo-political space. However, until relatively recently the great landmass of Central and Eastern 
Europe, to take only one example, was under the political control of only three polities, the imperial dynasties of Habsburgs, Romanovs and Ottomans (House of Osman). Despite sometimes conceding local levels of autonomy, these three dynastic realms controlled the destinies of large territories, including vassal states. Their power broke down in the face of nationalist uprising and later Nazi and Soviet territorial annexations, and ultimately the emergence of the independent nationality-based states revealed by contemporary maps. These three empires were 'loosely interpreted, polyethnic, polyreligious, and polylinguistic realms' (Brubaker 1996: 3) which controlled the lives of many peoples who didn't necessarily imagine themselves to be a single community, and whose rulers did not aspire to 'reflect' or have their ruled populations mirror them in ethno-cultural characteristics. The map of the landmass once ruled by only three dynastic houses now is a mosaic of small, selfgoverning and mostly ethno-culturally defined states.

For Brubaker there are various kinds of nationalism and different relations between states and underlying nationalities. A powerful culture-language focused kind involves recently independent states seeking to 'nation' their populations on behalf of a core ethno-culturally defined identity which 'owns' the state and whose advancement or defence the state is dedicated to because it is seen to be overcoming a legacy of discriminatory practices. This remedial or compensatory project of the state is contrasted to homeland, or 'trans-border' nationalism, in which excluded minorities seek to come to the cultural and political assistance of 'ethno-national' kin. A third kind involves subjugated minorities advocating for separation. The classic division in nationalist thinking has been between ethnicity based nationality and claims for statehood, contrasted with a civic basis for nationality and statehood, such as in the difference between the United States' conception of its statehood in shared citizenship despite ethno-cultural differences and the Japanese or Greek ethnicity based nationality (Anderson [1983] 1991; Gellner 1983; 1994; 1997; Hobsbawm 1992; Smith 1995).

Few modern states are exclusively of one or the other type and political entities that could resemble modern nation states have long existed, prototypically represented by the centralized and culturallylinguistically assimilating civic-based France.

In discussions of nationalism and its relation with language, the question of elites and masses often arises. In one view (Fishman 1972a; 2001b), elites 'organize' uneducated and non-politicized masses. National languages supply three kinds of raw material for the process of nationing that ethno-cultural states engage in: messages of cultural authenticity, instruments of efficient administration and tools for unification across class, region and ethnic divides. Miroslav Hroch (1996) has examined small national movements in central and eastern Europe and locates similar functions to Fishman's authenticity, efficiency and unification on a continuum. He identifies three recurring elements that seem to under- lie the press to nationalism in political movements. The first is a shared 'memory' of a common past functioning as a kind of 'destiny' of the group or of its core constituents. The second is a 'density of linguistic or cultural ties' that enables the group to attain a higher degree of internal cohesion via communication than exists beyond its boundaries. Finally nationalist conception requires claims to the equality of all its members, organized as a civil society (ibid.; also Connor 1994).

Hroch's comparative analysis of nationalist movements also recognizes uneven development of 'national consciousness' among various social groupings and regions and argues that this unevenness is arranged in a predictable set of phases. The initial phase consists of cultural, literary or folkloric activity that may often be conducted with little nationalist purpose. The outcomes of such archival, recording or documentary work on folk forms of marked languages, and also high literary culture, persuade mobilizers and nationalists that a distinctive entity exists and that if this distinctive cultural entity lacks political independence its existence warrants struggle to this end. A successive phase to this 'collecting' activity commences when the cultural information gathered by folklorists, scholars and cultural or literary figures is utilized as evidence of the national entity's existence and status by 'pioneers and militants' committed to the national idea. Political campaigning to make congruent the existing but stateless 'nation' with a unique administrative and distributive hierarchy (a national state) enters a third phase when it gains mass support for nationalist programmes. In these schemas from Fishman and Hroch we can see elements of the functions of national language revival movements, communicative and mobilizing functions, to solidify in-groups and direct them towards agitation for recognition. This activity is not inevitable but it is often divisive because group definition establishes boundaries with out-groups and language borders, marking language boundaries serves to constitute 'non-belongers'. 
In Language and Nationalism, Fishman (1972a: 5) defines nationalism as the 'organizationally heightened and elaborated beliefs, attitudes and behaviors of societies acting on behalf of their avowed ethnocultural self interest', actions which the nationalist seeks in 'the lower classes and the distant past' (8) because it seeks uncontaminated or pure representations of the marked language. Authenticity therefore functions in a complex way as both 'evidence' of continuation from the past and, as Hroch shows, a claim to a needed persistence into the future, both 'science' and 'political program'.

Symbolic functions of languages within nationalist reasoning are bolstered by functional communication needs, such as when Fishman points out that 'The functional dependence of new proto-elites on the vernaculars was a reflection of the need of these elites to communicate with, organize, and activate recently urbanized but still predominantly illiterate populations' (Fishman 1972a: 41). A marked language can, in the sense used by Bhabha (1990) 'narrate' the nation to itself. In this sense it is both the content of the language (its literary and folk forms) that initially constitutes distinctiveness and then in the hands of modernist nation making policies can form the raw material for high literary culture and 'intellectualization' of the code.

In a later hypothesis Fishman points out that 'nationalism is ethnicity rendered conscious and mobilized' (Fishman 2001b: 455), retaining his ethnicity-conscious framework, whose connection to the practical exigencies of state administration through standardized literate activities entrench language choices invoked by national language movements in pragmatic functions of governance, defence, education and civil administration.

Differences in historical context mark each national language revival movement in particular ways, so that the specific tasks undertaken for language revival and its accompanying ideologies can be widely different, such as the central importance of 'reducing' Pacific languages to writing (Mülhäusler 1990) or Dorian's (1977) discussion of the role and problem of the 'semi-speaker' in processes of imminent language death. Acknowledging the role of differences of context and history does not preclude comparisons which can reveal shared processes and new ways to categorize activity. This is clear from Spolsky (1996) whose analysis of the ordinary linguistic choices made by Israeli Hebrew speakers and New Zealand Maori speakers shows how a myriad of seemingly unrelated private decisions actually converge around or stimulate what, viewed from a wider perspective, is a policy of practice determined by small decisions of communication. Similarly, Ó Laoire (1996) contrasts and compares the situation of Irish and Hebrew at the beginning of the twentieth century, underscoring the unreliability of intergenerational transmission as the key mechanism for language revival. Ultimately such comparisons serve to highlight that languages are not independent variables freefloating above social arrangements. Instead communication choices are embedded in historically specific settings whose local circumstances implicate issues of power in economic, political and cultural relations among groups of speakers in multilingual environments. These comparisons reveal that language choices are highly situated and influenced by local histories of relations between groups, facts which impact on the kind of revival activity that is possible and appropriate in different settings.

However, the comparisons by Spolsky and Ó Laoire also show how similar policies can produce different outcomes and different policies occasionally produce similar outcomes. Convergence of outcomes from different policies and divergence from similar policies, does not suggest that there is anything portable across settings. Rather forecasting language outcomes from different settings is at the conjunction point of an inherited set of conditions and the desire, will and capability of mobilized action to change the direction established by inherited conditions. Both time (history and forecasted future) and place (local setting and its political and cultural configurations) establish trajectories which national language revival movements differentially impact depending on how they can mobilize and manage language planning activity.

\section{India}

India is home not only to many languages but also to many language movements, for both revival and maintenance (CIIL 1978, Dua 1993). Its linguistic diversity is among the greatest in the world with several major linguistic families represented among its myriad of spoken and written language forms. 
Among its 1.134 billion people, 76 per cent or $777,361,000$ speak languages belonging to the IndoAryan family, while $216,635,000$ or 21.6 per cent speak Dravidian languages. Other language families account for far fewer, so that Austro-Asiatic languages represent 1.2 per cent and Tibeto-Burman 1 per cent while others are below 1 per cent (Lewis, 2009). India is well known for recognizing multiple languages in its constitution. In addition to Hindi and English, twenty-two other languages are 'scheduled' achieving thereby official acknowledgement and a publicly recognized function (ibid.).

Unlike most equivalents the Constitution of India (Government of India 2007) provides an extensive section devoted to language. A section entitled Language of the Union, Chapter 1; 343 (1), declares: 'The official language of the Union shall be Hindi in Devanagari script. Followed by a specification of the form of numerals to be used for official purposes'; and then in clause (2) declares that English shall remain 'for a period of fifteen years from the commencement of this Constitution...'. (Gol 2007: 212).

Subsequent conditions of Part XVII Official Language stipulate that Parliament may extend the use of English beyond this fifteen years of both English language and the Devanagari form of numerals and supplies the mechanisms whereby such extensions will be effected. This is an exemplary case of the relations between language laws as public texts (Lo Bianco 2010), i.e. black letter law and language policy made in public debate. This underscores how constitutions operate as public texts, in effect acting as a solidified conversation, but remain open to further elaboration, interpretation or change through public debate. This relationship further depends on what individuals and institutions, especially powerful elites, actually do in their performative language use (ibid.), so the three mechanisms of language policy making, texts, talk and behaviour are linked in a cycle of activity. Texts are slow to change, discourse is iterative and dialogical and behaviours are speech acts located in the here and now that either reinforce, interrupt or modify what formal texts stipulate.

The continued extensions to English in Indian official life underscores this dynamic relationship between a public text and public discourse around language, and in turn their relation to what people actually do. The Constitution in its successive clauses attaches progressive use of the Hindi language' to 'restrictions on the use of the English language' epitomizing the tension between desire and pragmatic realities. In a series of clauses from 344-351 in which English is circumscribed in time and function, Hindi and English are designated 'official' but these are ranked so that Hindi enjoys the standing of principal or first-named official language, speaking to its association with nationality, and English is the second-named, or secondary, official language. The Indian polity is a Union, whose constitution stipulates not simply these official designations but also describes its first official language as 'Hindi in Devanagari script'.

How this particular Indian way to organize the legal and official standing of its languages has arisen reflects India's historic encounter with foreign languages. This is a multiple and ancient encounter, more than three millennia of language contact within which two interactions predominate. These are external language contact experiences, with Persian and English, which have had significant and enduring influence not only on the linguistics of language contact but also on attitudes, ideologies and policies and it has been in reaction to this history of colonially imposed languages that the bulk of national language revitalization efforts have been directed. According to Singh (1996), the narrative of colonial relations inscribed in Indian public discussion persists despite the overcoming of the actual conditions of colonial subjugation. Since many debates are framed in a continuation of the categories and concepts of domination and dialogue that colonialism bequeaths he sees a 'continuing validity of the colonial paradigm' shaping Indian thinking from the seventeenth century onwards. In his analysis Singh exposes a flow of continuing references organized by the discourse of colonization, from early modern encounters to the Raj and their continuing presence in the Indian nationalist state (ibid.).

The establishment of a communication order for India is a question of profound interest for sociolinguistics, partly because of the deep complexity that characterizes the Indian setting but also because of the turbulent and contested history of its language planning. While it is warranted to celebrate and recognize the naturalized multilingualism of ordinary life in India its diverse linguistic ecology has not inured the country from bitter political rivalry among language groups. Despite the scale and depth of the linguistic issues involved there are still pools of homogeneity, so the presence of elites sharing a relatively homogeneous variety of English has been a tool of integration and aggregation around shared ideas, especially the modernizing discourses forged within India's long dominant Congress Party during the independence struggle and the early years of political 
mobilization.

Contrasted with this relatively stable and uniform linguistic order at the peak of the Indian political structure there are also 'on the ground' politics of industrial and agrarian competition in which language differences compound poverty, marginalization and exclusion (Friedrich 1962).

Giving this theme a linguistic character is the analysis by Ghosh (2004) which holds that in the context of local separatist movements that were prevalent in India during the 1980s, the country found itself in the paradoxical situation of having constitutionally planned for the dislodging of English from public life but needing continually to extend its presence. Each extension has tended to entrench its ultimate and now probably permanent hold. No single indigenously Indian language was capable of dislodging English, and the parameters of efficiency of administration which govern how contemporary states are conceived favours a monolingual solution to public administration, or at least a solution predicated on only a small number of languages sharing the total communicative load. As a result as growing numbers of Indians speak English domestically its Indianization proceeds as does its indigenization (Kachru 1983). The political and economic liberalization which has taken root since the mid 1990s has produced a major spurt of economic growth and deepened the hold of English.

This hold of English is far from being the exclusive preserve of elites. A newspaper report entitled 'Tribals demand English medium', published in the Andhra Pradesh Chronicle of 18 August 2009 in Adilabad, reads in part: 'Tribals in the district are against their children being taught in the MT and have demanded that English be the medium of instruction in the newly introduced "MT tribal schools". They opine that their children will not get a competitive edge without English...' The article goes on to claim that Adivasi (tribal) languages Gondi and Kolami were introduced into schools in 2009 and cites Adilabad member of parliament, Mr Ramesh Rathod as a strong opponent of this move. It cites his description of mother tongue schools as 'a conspiracy against' the Adivasi.

Fishman's three criteria for the role of languages in national movements, authenticity, efficiency and unification, play out in often contradictory ways. English is denied the former, claims the second and contributes to the latter, but Hindi in south India struggles in some areas with the former, and shares the latter two with English. Despite its characterization as inauthentic for the Indian context, the extended roles of English in Indian life suggest a wider discourse is required to explain its continuing presence in Indian public life and increasingly beyond the domains of commerce, education and technology.

In search of these alternative accounts Ghosh (2004) studies writing, both novels and 'journalistic prose', during the 1980s to uncover the characterizations of English, concluding that its association and functional role as 'tool of modernization' and tool of technology have bolstered its hold, in addition to its adoption and maintenance as a language of power and opportunity by middle-class interests. However, this analysis is incomplete since in some domains both Hindi and Bengali emerge as 'hegemonic' within a diverse range of usage domains unavailable to English. Ghosh's analysis shows that the promotion of Hindi has been 'deleterious' to the status and social functions of Urdu, and that 'Bengali and other regional standards' are imposed on local dialects and therefore tend to function in these settings as a force achieving power and position for those who identify with each standard form.

As a result India's national leadership has made recourse to a 'three-language' compromise. The multilingualism of the population has therefore meant reliance on translations, and the direction of translations from official function languages to regional or state standards has tended to 'stabilize' English, Hindi and state or regional standards (Ghosh 2004). The result is that the mechanism of constitutional extension of English is continually activated to respond to 'on the ground' realities of communicative roles, entrenching what was intended to be a temporary expediency.

This compelling analysis of the heteroglossic situation of Indian communication, private and public, personal and institutional, shows how national language revival movements are always positioned within complex local language ecologies and are constrained by them as much as they try to alter them.

This linguistic ecology has within it the residues of the Gandhian moment in Indian language discussions (Trivedi 2003). During the beginning phases of nationalist agitation in India, when it 
moved from an elite to a mass phenomenon across colonial South Asia the swadeshi (indigenous goods) movement was installed in public debate by Mohandas Gandhi as the stimulus for 'home rule', swaraj. Gandhi predicated this on economic self-sufficiency since its opposite, economic dependency, had been a critical feature of colonial subjugation. The image and the metaphor of Gandhi's swadeshi politics were located around khadi, hand-made cloth produced locally and used in preference to imported goods (ibid.). National language choice drew power from the swadeshi movement, a sort of selection, propagation and acceptance of the language version of khadi, but one which both in the early days of nationalist mobilization, and still today, has produced both conversation and contestation. The political sociology involved in national language mobilization, reaches far beyond the three language formulation of Hindi-English-state/other language (Dua 1993), to raise questions of local and cultural identities. As a result the number of movements identified by linguists, census takers and linguists in which particular languages are put forward for recognition number hundreds, traced to well before independence. This longstanding and turbulent history of language mobilization has been a recurring feature of politics in the subcontinent producing conflict and sometimes violence, but also compromise and cohabitation. The compromise arrangements for organizing local communication among various alternatives which are arranged hierarchically and functionally, have deep consequences for the social standing and opportunities of speakers (Brass 2004).

Many of India's numerous language movements do not strictly belong under the tag of 'national' since they do not aspire to independent statehood in a more or less political sense; however, recalling Hroch's sequencing of national language movements, Dua (1993) points out that movements which commence with one set of aims often acquire additional or different ones as they mature. Dua stresses that these language mobilizations have mostly been competitive, a common premise being to demand not only linguistic recognition but preference, with the concomitant displacement of actual or potential rival languages.

Two overarching factors conditioning language policy during the twentieth century have been the standing of the Congress party and the relative power and aims of Hindu nationalism. How Hindu nationalism has characterized the role of English is especially critical for its rebounding effects on other languages, and has been a critical and at times explosive theme in Indian politics. Hindu nationalist activists have varied in their choices and views of English, Hindi, and state or regional languages. In research focusing on a range of diverse historical sources in Uttar Pradesh in the final stages of Britain's colonial power in India during the lead-up and choice for Partition, Gould (2004) shows how Hindu nationalism impacted on the ostensible secularism of the Congress Party. The north Indian Muslims are the population most directly affected by the relations between Congress which avowedly championed their status, and Hindu Nationalism which had to decide among alternative options to pursue a re-emphasis of traditional Indian Hindu ideologies, including language, post-independence.

In these disputes language revivalism was shaped by the legacy of the older Persian and more recent British language policies. During the eighteenth and nineteenth centuries these were distilled into two overarching discourses, Orientalist and Anglicist, and administration, education and justice oscillating between them. Although they disagreed about methods and action they shared a common ambition or presupposition that British dominion over India would remain. A key point of dispute between these orientations concerned the interpretation of the impact of Perso-Muslim influence in Indian life.

Both of these views, the ultimate cultural regard for India, and the role of the system of languages and structure of administration inherited from the Muslim rulers, were tempered by the pragmatic needs of running India. The choices available to the British were to pursue or reinstate vernacular communication with their new subjects, or accept the vehicular role of inherited languages and systems used by the Muslim rulers, and what these choices would imply for the shared desire to implant English as the auxiliary, and ultimately dominant language of the subcontinent. In prePartition India large territories and civil administrative structures were Muslim in character and history. Education and local administration of governance and especially of the lower courts were the key sites of these language management choices where Rahman (1996) identifies three phases: an initial Persian, Hindustani and Sanskrit based policy in the 1780s shifting to an intermediate phase in which local languages were preferred in lower courts and local administration to a more full-blown adoption of English from the 1830s. In this analysis the Orientalist-Anglicist controversy acts as the 
manifestation in language policy terms of an underlying British attitude and understanding of India and the sub-continent more widely in the early nineteenth century.

The historical recycling of inherited communicative choices, and the new circumstances of a globalizing economy in a secure and independent Union of India, show that national language revival movements are an enduring feature of public life since new communicative demands and circumstances arise continually.

\section{Indonesia}

Among broadly comparable Asian countries in Southeast Asia, such as Malaysia, Singapore or the Philippines, Indonesia has achieved comparative success in the development, public acceptance and diffusion of its national language (Alisjahbana 1971a; Dardjowidjojo, 1998; Guan and Suryadinata 2007). One account has it as 'perhaps even the most spectacular linguistic phenomenon of our age' (Alisjahbana 1962: 1).

No national language revival movement begins its efforts in the absence of raw materials of language, nation and the means for agitation and organization for revival, but perhaps Indonesia's case was better supplied with an accepted local lingua franca in parts of the Indonesian archipelago, Malay. In Dardjowidjojo's view however, this felicitous beginning masks the real reasons for the success, which lie instead in socio-political factors, particularly the language policies of the colonial countries, the responses by early nationalists, the rivalry between the national language and either the vernaculars or the colonial language, especially English, and the successful cultivation of the national language after its adoption. These factors supply relatively favourable conditions for the penetration and development of modern Indonesian into society, conditions analysed as a series of solvable problems attributed to competent agencies involved in standardization and language spread (Rubin 1977). Early writing on the success of Indonesia's national language movement often relies on this pragmatic, problem solving approach, such as language planning as a series of engineering steps in response to identified communication obstacles hindering national unification (Alisjahbana 1971b). Indonesia experienced a rather concentrated process of decolonization, despite an intervening and brief Japanese re-colonization (regarded by Alisjabhana 1962 as decisive), which links the making of Indonesia (Lev and McVey 1996) to the making of Indonesian. The close sequence of events, more recent and more public than in the case of other national language revival movements, have seen a close connection between enacting language decisions and observing their effects. The Indonesian state, whose philosophical foundation is expressed in the Sanskrit derived term pancasila, or five national principles, is built in various ways on the inevitability of having to reconcile immense linguistic, ethnic, geographic and religious diversity, in uniquely Indonesian ways.

The functions and 'systems' of Malay in its form of Bahasa Malaysia is tied also to Malaysia's independence from Britain in 1957 and its expansion from vernacular, to national, official and state language, to a language of commerce and science (Omar 1983). The main preoccupation has been corpus and specifically terminological expansion and the formulation of a standardized spelling system. In this process the overarching rules have been jointly negotiated between Malaysia and Indonesia, but alongside this shared intervention to manage a shared language resource have been diversifying tendencies that have come largely from unplanned development of the language due to borrowing arising from culture contact arising from Hindu-Sanskrit, Muslim-Arabic and AngloEuropean sources.

However, Indonesia is a much larger country than Malaysia, the fourth most populous nation in the world, the world's largest Islamic society and more linguistically diverse, with Ethnologue listing well over 726 languages (Lewis 2009) across a range of language families. Of Fishman's (1972a) three language in nationalism factors - authenticity, efficiency and unification - Indonesia has derived most benefit from the latter by its successful adoption, cultivation and propagation of the language.

The origins of Indonesian in the pre-colonial period, and the emergence of Classical Malay from the fourteenth century (Nugroho 1957; Sneddon 2003) are a necessary backdrop for the more intense connection between communication and political community in the concentrated pre-independence period. This long process is traced along five stages by Daud (1996), who concurs with other scholars that adoption of Malay was facilitated by its existing informal and lingua franca function 
throughout Malaysia, a role stemming in large part from its use in the propagation of Islam. This felicitous status combined with a declaration by the Dutch colonial administration that Malay would function as co-official with Dutch in the Volksraad, a 'proto-Parliament' (established 1916 but convened in 1918), containing fifteen native-born Indonesian representatives among its thirty-nine members.

This formal acknowledgement of the wider function of the language lays the ground for its later acceptance. Anticipating and helping to create its eventual adoption was a crucial act of terminology change, the Sumpah Pemuda or 28 October 1928 Youth Pledge by nationalists, proclaiming 'one motherland, one nation' and naming 'bahasa Indonesia' as the 'language of unity'. This public text and renaming of Malay established its unique function. The Sumpah Pemuda is emblematic of the goal of national language revival movements to name languages after peoplehood, connoting sentimental attachment between one and the other, even when, as in this case, the bonds were to be created as much as assumed. The Sumpah Pemuda converted $\mathrm{BI}$ into a symbol of nationalism and resistance to the colonial Dutch (Alisjahbana 1966). Daud's fourth state is the indirect endorsement of Bahasa Indonesia by the occupying Japanese during the Second World War. Embracing Bahasa Indonesia and the prohibition of the use of Dutch served both pragmatic and ideological functions, intended to detach native Indonesians from their European colonial masters. That this move was enacted by a colonizing Asian master does not alter its ultimate symbolic power and underscores the growing internal identification of Indonesian nationalist elites with Bahasa Indonesia. The final stage in Daud's schema relates to 1945 when Indonesian national leaders seized power in the wake of Japan's defeat and the temporary absence of Dutch colonial administration and in this breach declared Bahasa Indonesia the national language. These moves establish a sequence of symbolic and then practical functions for Bahasa Indonesia, its renaming signifying a desire to naturalize its association of serving as a unifying common language.

The subsequent process of diffusion across the archipelago in its official roles as a 'national language', i.e. a code of identity for the diverse ethnicities and peoples of the new state, and as a state language, i.e. as a language of public administration, but also as a language of convenience in general for communications and commerce, comes about through a protracted process of deliberate language planning (Alisjahbana 1971a, 1971b; Rubin 1977). A key instrument in the achievement of these aims was the elevation of literacy standards and literature (Alisjahbana 1962) enshrining BI as the principal reading language for most Indonesians. A consequence of its often exclusive use as medium of instruction for the national school curriculum, Bahasa Indonesia emerges as the preeminent literary language of Indonesia, the language of common writing as well as reading (Diah 1982).

The effect of this extended process of officialization and nationalization meant that by 198660 per cent of the population had some competence in Bahasa Indonesia, a substantial increase over 1971 (Nababan 1991). The 1945 constitutional declaration of Bahasa Indonesia as state language combined with reformed spelling norms of 1972, supplied the legal and educational remit for its spread. For most of the national independence period it has served as sole medium of instruction, exceptions were permitted in only nine regions for local vernaculars for three elementary school grades. Despite minimal leniency, the pragmatic needs of communication in classrooms have meant much more use of languages known by children, if they share a language with a public school teacher. Vernaculars are often taught as subjects including in the nine regions that permit them as teaching media for initial literacy.

As a result of this process of diffusion Indonesian language-in-education planning has produced a spreading bilingualism throughout its many islands resulting in multiple language competencies, with a three and four language knowledge combination, BI with one or more vernaculars. Rapid expansion of English in recent years, dislodging the extra-national communication functions previously held by Dutch (Groeneboer 1993), further extend the multilingual repertoire to encompass sub-national plus national plus extra-national language competencies: Indonesia's formulation of local and regional vernaculars, Bahasa Indonesia and English. Competence in English remains geographically and socially stratified, being mostly among the young, educated and urban.

An important feature of Indonesian national language propagation has been a widespread diglossia. Bahasa Indonesia is reserved for official purposes at every level of public administration but domain separation with personal, local commercial and cultural life means that vernaculars are rarely 
endangered by expansion of Bahasa Indonesia, although this is not true in all cases. The language diversity extends well beyond what is named as different languages, so that within towns and regions speech styles reflect notions of community and hierarchy that are locally applicable and relevant. Public authority and public language are only one dimension of the lives of people. Interactional forms arise in contact situations where public authority representatives are themselves second language Bahasa Indonesia users, giving rise to complex interactional speech styles across Indonesian life.

In close examination of the largest example of this, Java, Errington (1998) reveals choices of code, switches and patterns are dictated as often by micro-interactional relationships as by large picture national patterns in which identity is negotiated and displayed in continuously dynamic ways. Also working in the Javanese-Bahasa Indonesia framework is Smith-Hefner (2009) who notes a shift away from formal styles of Javanese to the use of Bahasa Indonesia among youth schooled in the national language, responding to new educational and social opportunities, and how these reflect and help produce gender differences in language. The dynamic nature of interactions revealed in this work underscores that even within the widely accepted depiction of Indonesia as having successfully spread $\mathrm{BI}$ across its geo-political space, and the regularly made claim that this has not endangered vernacular languages, for even very large languages like Javanese, extensive language change does occur as new possibilities, combinations and arrangements arise that alter language use patterns. The officials ruling local people in the 'scattered settlements of Sumba, Roti, Timor, and other parts of eastern Indonesia' (Keane 1997) have by turns been Portuguese, Dutch and Indonesians, representing and acting as centre elites and interests interacting with 'locals' whose adaptation and responses have always utilized a sense of the irreplaceable role of the 'local' and of 'knowing one's place' (ibid.).

At a macro level, however, it remains true that a generalized hierarchical diglossia has arisen, with $\mathrm{H}$ functions allocated to the state language and $L$ functions reserved for local languages, since their spheres of operation are more and more restricted. In Nabadan's (1991) analysis Bahasa Indonesia fulfils cognitive, instrumental, integrative and cultural functions, while vernaculars are reserved for only integrative and cultural purposes. While this schema masks considerable overlap between these functions, Nabadan claims that the centrally prescribed national curriculum is essentially 'pragmatic' or 'communicative', meaning essentially that it is expressed in a standard syllabus for course books. In the extensive analysis of the curriculum of the 1980s offered by the author, the syllabus organization reflects expected social roles and functions, according to the four-part division into cognitive, intellectual, integrative and cultural areas. The system of education of course is too multifarious to allow simple classifications for the entire nation, and hence both non-formal education, and the basic education and literacy programmes delivered nationally, utilize only Bahasa Indonesia while there is extensive deployment of foreign languages to teach content in vocational courses for commercial ends.

\section{Israel}

While fixing language and fixing nation are central mobilizing forces in national language revival, supremely true of Hebrew and its national home of Israel with the emergence of political Zionism in the nineteenth century, the language's establishment preceded the founding of the nation. In the context Hebrew had to overcome its rivals (Safran 2005) to emerge as the compromise between Eastern European immigrant Yiddish and the Arabic or Ladino spoken by Middle Eastern Jews, and later still by educational roles accorded to French and German. The re-emergence of Yiddish with the mass admission of the remnants of East European Yiddish-speaking Jews elevated the question of language choice again. The status primacy of Hebrew had by this stage not been secured and the threat posed in Yiddish was systematically confronted by the national leadership (Safran 2005).

Essentially then, two phases have characterized the revival of Hebrew in Israel's nation-building: the first famously occurred in the latter half of the nineteenth and early part of the twentieth centuries and consists essentially of what Fishman (1991) has called re-vernacularization, extending to speaking a language that had long been used in reading and writing, and functionally from religious and literary domains to everyday functions. The second phase 'after 1920 when there were already fluent native speakers...was revitalization' (Spolsky 1991) - 'the re-establishment of natural intergenerational transmission as new parents who had learned the language in school began to speak it to their babies' (also Spolsky 2009). 
This 'renaissance' of modern Hebrew (Blau 1981) is an exemplary case of institutionalized language planning (Saulson 1979). Texts and institutions were inspired and extended by individual language champions, most deeply by Eliezer Ben-Yehuda (1858-1922) lexicographer, newspaper editor and critical force behind many revival initiatives (Fellman 1973) such as the creation of the precursor for the Academy of the Hebrew Language, the Va'ad HaLashon or Committee of the Hebrew Language.

Long depicted as practically miraculous the revival of Hebrew as a living language and the product of Ben-Yehuda's driving spirit and dedicated planning, particularly in domain extensions typified by a corpus planning based on confronting practical problems of communication which impeded full use of Hebrew followed by codification activities (Nahir 2002, Harshav 2009).

Recently Zuckermann (2006), perhaps celebrating the remarkable achievement of both phases, collectively constituting full revival (re-vernacularization plus revitalization), celebrates this success in a humorous but still serious way and calls for Hebrew to undergo perhaps the final phase of full normalization, being itself renamed 'Israeli'.

The full revival of Hebrew gave the language the two complete and self-contained intergenerational transmission systems that healthy languages enjoy: intimacy (i.e. raising children in the language) and instruction (formal teaching). These work in tandem so that primary and secondary socialization, families and institutions, collaborate to supply a full spectrum communicative medium for new Hebrew speakers. The nation, always an impelling force for language revival, was for Hebrew within the Diaspora, a nation lacking a state, but made complete with Israel's declaration of national independence on 14 May 1948. A declaration is also a language act, a public text, making real what is emerging in concrete terms, so that the Hebrew language achieved a political administration to add to its millennial nation of affiliation and identity.

In this act of national creation there was also the eclipse of European Yiddish as cultural politics and Jewish writing paved the way for modern Israeli culture, while de-legitimizing the alternative flourishing literature. This alternative 'persisted for many years - in conversation, in newspapers, and in songs' (Chaver 2004) in the multifarious 'cultures of the Jews' (Biale 2002). This eclipsed Yiddish however (Bliss 1997) is itself today object of re-invention in the Diaspora, especially within some Hasidic sects and in the US, through Yiddish theatre, literature and klezmer music (Bliss 1997) and serves to problematize the idealized nation-state speaking a single and exclusive language. In this process not only Israel is construed as a place of many tongues but multilingualism is extended to Jews everywhere (Gold 1989).

The resolution of a clear status of Hebrew became extended in acquisition and usage planning for new arrivals in the provision of Hebrew study for adult immigrants in the ulpanim. This intensive instruction system was created in 1949 to provide for the massive influx of new arrivals and refugees, later catering for new communities from Africa and elsewhere across the Middle East.

Among these disparate and multinational arrivals the ulpanim provided cultural inculcation which continues today, though their effectiveness and longevity have come under question (Sanbatu 2007). Over its life ulpanim have graduated more than 1.3 million people in a process of more or less ordered integration into modern Israeli cultural, social and economic life, a process now projected outward transnationally re-energizing Diaspora communities and networks of language study (BenRafael and Sternberg 2009).

This now-revived language extends beyond its ancestral associations to incorporate all citizens of Israel, including Arabs, with new sociolinguistic possibilities arising from migration, urbanization and language spread. Hebrew also enters new relationships of sharing the communicative load of the modern citizens of an increasingly multilingual polity exemplified by the complex cases of Israeli cities and the patterns of domestic use of Arabic, the nation's other official language (Amara 2005) as well as Palestinian villages with histories of dislocation, conflict and divided loyalties (Amara and Spolsky 2001).

Like all modern societies Israel struggles with claims on its public resources for educational and citizenship services and administration arising from migration and concessions to non-Hebrew speakers (Herzog and Ben-Rafael 2001) in which the politics of language and identity reflect shifts of 
tension and co-habitation, sometimes 'words' and sometimes 'stones' (Lefkowitz 2004). The collective identities of minorities within Israel, non-Israeli Palestinians and Israeli Arab speakers and immigrants proceed as in all states with the added quality of being negotiated under conditions of persisting tension and conflict.

\section{Ireland}

The Constitution of Ireland (Bunreacht na hÉireann) came into force in December 1937 after a national plebiscite in July 1937, to replace the original founding document of the Irish Free State, through which the independent Irish state first emerged.

The 1937 Constitution was inspired and is characterized by the nationalist impulses of the Fianna Fáil government of Éamon de Valera and signifies and symbolizes the full replacement of the UK government- imposed 1922 constitution. The Bunreacht was drafted in both English and Irish by Micheál Ó Gríobhtha and in English by John Hearne, with prevalence allocated to the Irish version. Recalling the Indian case the Constitution discusses names and naming; the English name of the state is Ireland but Éire in Irish, with the expression Republic of Ireland decreed the official description, rather than the name of the State. The languages are also named and functionally allocated:

Article 8.1 The Irish language as the national language is the first official language.

8.2 The English language is recognized as a second official language.

8.3 Provision may, however, be made by law for the exclusive use of either of the said languages for any one or more official purposes, either throughout the State or in any part thereof.

Official naming extends into Irish words used in English, so that Taoiseach is the preferred description for the head of government (DoT 2004).

Beyond the Constitution, special status is accorded to Irish through the Official Language Act (OLA) of 2003, Education Act of 1998, Planning and Development Act of 2000 and the Broadcasting Act of 2001. The Official Language Act is particularly important because it accords the right of public use to Irish in state dealings, extended from 13 June 2005 to be a working and official language of the European Union. In light of these legislative remits in 2006 the Irish government released a Statement on the Irish Language and commissioned a twenty-year Strategy for language revival (Ó Flatharta, Nic Pháidín, Williams, Grin and Lo Bianco 2009).

Ireland represents a case of failure and success, conquering all areas of formal legal recognition but marked by relative neglect of domain normalization. Markedly absent for Irish are commerce and daily public interaction, so that today usage of Irish is still marked by the ordinary needs of marginal populations and regions and sustained by the advocacy of the committed. Irish has always had a central symbolic place in the contested but powerful ideas of Irish nationhood (Kearney 2007). Predictable symbolic markers of faith, language, territory and shared history recur throughout Ireland's long struggle to secure an autonomous political separation from the United Kingdom and its historic policies of negation and oppression of Ireland's unique character, even if the symbolic markers were not always aligned and mutually reinforcing. A key challenge has been that overarching British, as distinct from English, identity has long been constituted as a civic norm permitting an ethnicity basis for the constituent homelands of Wales, Scotland and particularly Ireland. Separating from this has required the independent republic to add elements of its own civic nationality to its originating ethnic dimension (Sutherland 2000).

The notion of unique tongue and nation animating language revival activity is distributed across the cultural geography of place (Graham 1997). In Ireland's case this is both physical and ideological, regionalized geographically and marked by preservation thinking which supports the Gaeltacht Policy (the west and islands) and conflicts of territory with and about Ulster (the north and northeast) of the island, but also extra-nationally within the Irish diaspora and especially within Britain. The physical proximity to England and its expansionist trajectory have made of Ireland a primary world experience of ceding geographical space and conceptual domains to English, as conquest of its territory and cultural subjugation were partner notions in the project of colonization (Palmer 2001). 
The texts on language from the earliest anti-Irish laws, e.g. the 1366 Statute of Kilkenny to the Belfast Agreement of 1997, all involve the overarching theme of the division of geographic space, the territory of the island. Because of this even ancient acts of language restriction resonate today (Crowley 2000, 2005) as they enact new chapters of a continuing political story, punctuated by the Reformation and Counter Reformation, modernization, grievance, the great famine and struggles for political emancipation. Despite long duration and struggle the overall trend has been constant. Irish language capabilities and daily usage have steadily retreated geographically and contracted communicatively, to ever more marginal territory, fewer numbers and smaller domains. Mapping the space tells a deeper story of conceptual, ideological and cultural movement westwards, inwards and downwards: to promontories, rural and isolated zones and remote islands. Both aspiration and agitation for national language revival in Ireland have therefore always made central the idea of conservation of zones of exclusivity for Irish, often interpreting bilingual policy as fatally predictive of erosion. In the post-independence period the spatial and geographic pattern has been buttressed by pragmatic considerations such as public administration delivery (Ó Riagain and Gliasain 1984) and predicated on the right of access to state services and entitlements.

Gaeltacht zones therefore have been imagined as beachheads for revival and bulkheads against attrition. Compounding Irish language policy have been persisting correlations of English with higher social class and occupational and educational opportunity (Ó Riagain 1997), an often fatal connection of development with English.

The past five years have seen reinvigorated planning for Irish, with an awareness that a disproportionate effort has been devoted in the past to politico-legal activity and acquisition planning and too little to use planning. While top-level activity continues, most dramatically the decision to include Irish as an EU official and working language (O'Riain 2009) increased effort is now devoted to its practical functions in daily life. Continuing decline in its use by young people in the Gaeltacht has inspired a shift to identifying a role across all social life in the country, buttressed by provisions of the Official Language Act and now enshrined in an ambitious usage-centred twenty-year strategic plan. Electronic media, education, commerce and employment as well as public culture feature in the measures adopted through the twenty-year strategic plan (Ó Flatharta et al. 2009).

\section{The survival of the nations and national languages?}

The predicted demise of national states (Ohmae 1995) in the face of mass global culture and the networked trans-national capitalism of the 'new economy' (Castells 2000a) or the immense pluralizing effects of the Age of Migration (Castles and Miller 2009) is logically extendable to national languages. The growing civic basis of many states founded on ethnic and nationality principles are accelerated by their transformation into advanced capitalist economies and liberal democracies.

True of both Ireland and Israel, in the latter case it raises a perplexity connected to citizenship and belonging because of the ambiguous status of foreign labour (Kemp 2007). In common with other affluent nations Israel imports foreign labourers from developing countries, such as Romanian construction workers, Thai agricultural labourers and Filipino caregivers, ostensibly for fixed term employment in jobs shunned by mainstream citizens but also sidestepping the politically complicating option of hiring Palestinians (Drori 2009) so that citizenship is now managed and distributed within an already defined and stable Hebrew speaking and institutionally secure context. It isn't just adults who arrive, and usually remain despite the supposedly temporary basis of their admission, but also children and so Hebrew acquires new modes of transmission and new forms of expression, as an additional acquisition for bilinguals with clear but usually subtractive mother tongues.

In response to these perplexities it is wise to be mindful of Alpher's caution regarding the 'four institutions that, despite the best efforts of radical revolutionaries for over a century, never seem to go away: state, nation, language and religion' (1986: 1). Both nations and national identities offer continuity within the growing linguistic mosaics of contemporary states, and nation and national feeling adapt and persist even under conditions of globalization, tourism, mobility and world English (Wright 2004; Young, Zuelow and Sturm 2007). New challenges to citizenship have revealed the adaptability of national states as much as they have exposed their fragility in the face of the need to import labour and trade globally. 
The globalizing context affects India and Indonesia in particular ways too, less through immigrationbased diversity and more through globally exposed requirements for English. In India's case, since English had long been the other against which national language mobilization operated, English is now construed as a basic skill facilitating its economic success of recent years, and in call centres, IT and other 'new economy' sectors as a critical asset. National language revival movements are still vibrant across India's mosaic of language contexts but their assertion serves to enshrine the three language formula.

Bahasa Indonesia is secure as Indonesia's revived language of national identity, unification and administrative-educational efficiency, and has extensive regional functionality within South East Asia, despite institutional ties, mostly the Association of Southeast Asian Nations, and other political and economic realities being dominated by English. Despite occasional claims of extensive 'attitudinal resistance of Muslims towards English' believing that it is 'rooted in the Judeo-Christian culture' and an instrument conveying 'Western' values (Ratnawati 2005) it functions as the metalect for Indonesia's global interactions beyond its national and immediate regional connections.

National language revival movements, in all the cases identified, have aimed to retrieve lost natural communication patterns. They have often had to assist in constructing the nations the language was supposed to reflect and exemplify. In all cases other than Ireland the institutional security of the marked languages, Hebrew, Hindi and Indonesian, is matched by naturalistic transmission and daily interaction.

In contemporary thinking identity is more often considered not as a stable, enduring given, but rather a constructed entity, subject to continual change and ongoing construction and located in historically particular circumstances. It must follow, as national language revival movements suggest, that if the wider identities are constructed and not in any way natural, then so too are local identities, so that no identities may be taken as primordial and essential. However, their continuing existence must suggest that despite being objects of construction or manufacture they are no less real than if they were as natural as many nationalist advocates believe.

The four national language stories discussed all show palpable success in national language revival to some degree, but in no case absolutely, in the case of Irish marginally, in the case of Hindi strongly and in the case of Hebrew and Indonesian emphatically. However, neither spatial location, nor shared history, were sufficient to persuade all potential members of the four national language community that they belonged together naturally. In all cases contemporary globalization, mobility and economic forces are imposing new solutions of pooling the communicative load of the languages from below and beyond the national level.

The contemporary world poses new and particular threats to the underlying national state on which national language revival has been premised and also to the national language, or at least restraint on its spread and distribution. The threat imposes on national language movements pressure for protection, from below and from beyond. The pressure from below is for internal coherence as the increasing assertion of the local and rapid diversification through immigration, threaten fragmentation. The pressure from beyond is represented by the increasing presence of world English and regional languages within national boundaries through locally present communities linked horizontally beyond the national domain.

National language movements are under pressure to abandon their old claims for communicative homogeneity and exclusivity and plurilingual alternatives respond better to the pragmatic realities of contemporary life. Both geographic space (territory) and institutional discourses (domains) admit increasing diversity through population mobility and economic integration. As yet this does not appear to presage the loss of national languages but the loosening of their exclusive claims on the communication repertories of their native users. Instead national language movements which in the past mobilized against the colonization of national space and institutional domains by imposed foreign languages, or the absence of political sovereignty, now negotiate new roles in the lives of non-native users and expanded lingual capabilities among natives. Expanding to admit multilingual possibilities and differentiated forms of communication is a challenge for the creation of a new version of the national language story rather than its termination. 
Old notions of community imagined the national language forged in the prism of the proximity of local interaction, through the re-iterated encounter of living together and forging denser relations with cocitizens and therefore greater identification with them. This notion has undergone extensive revision in light of Benedict Anderson's (1991) influential depiction of community as existing in the active 'imaginings' of its members. The national language movements recounted here do not support either extreme of the possible interpretations, that elites impose forms of belonging and language on unwilling masses, or that the masses demand from below the construction or restoration of old forms of communication in new national and institutional entities.

We see instead a much more complex picture, in which borders, between languages as between political entities, of economies and of cultural forms, are often about scale of reference, about combinations of local and extra-local and are usually incomplete and sometimes contested. 


\section{University Library}

\section{- M M N E R VA A gateway to Melbourne's research publications}

Minerva Access is the Institutional Repository of The University of Melbourne

Author/s:

Bianco, JL

Title:

National language revival movements: reflections from India, Israel, Indonesia and Ireland

Date:

2012-03-01

Citation:

Bianco, J. L. (2012). National language revival movements: reflections from India, Israel, Indonesia and Ireland. Spolsky, B (Ed.). The Cambridge Handbook of Language Policy, (1), pp.501-522. Cambridge University Press.

Persistent Link:

http://hdl.handle.net/11343/112277 